\title{
Improvement of protein extraction efficiency from defatted sesame meal with thermal and enzymatic treatments
}

\author{
Man-Jin In $^{1}$

\section{열 처리와 효소 처리에 의한 탈지 참깨박 단백질의 추출율 향상}

인 만 진 ${ }^{1}$

Received: 19 August 2020 / Accepted: 31 August 2020 / Published Online: 31 December 2020

(C) The Korean Society for Applied Biological Chemistry 2020

\begin{abstract}
In order to increase the utilization of defatted sesame meal (DSM), a by-product of sesame oil production, the conditions of extraction of insoluble proteins from DSM by enzyme treatment were investigated. As a result of comparing the treatment results of proteolytic enzymes Alcalase, Flavorzyme, Neutrase, and Protamex with control, Protamex was effective in increasing the total solid and protein content. At the reaction conditions of Protamex $\left(50^{\circ} \mathrm{C}, \mathrm{pH} 6.0\right)$, the dosage of enzymes was appropriate for $1 \%$ of DSM and $3 \mathrm{~h}$ of enzyme reaction time. To improve the efficiency of enzymatic treatment, the protein content extracted increased as the heat treatment temperature increased, and slightly increased above $110{ }^{\circ} \mathrm{C}$. As a result of investigating the effect of the combination treatment of cell lytic enzyme (Tunicase) and protease (Protamex) on protein solubilization, it was most effective to treat the cell lytic enzyme after processing the protease. After heat treatment $\left(110{ }^{\circ} \mathrm{C}, 10 \mathrm{~min}\right)$, sequential treatment of Protamex and Tunicase increased the protein content by about 3.5 times $(9.85 \rightarrow 35.58 \mathrm{mg} / \mathrm{mL})$ of the non-heated control and 2.2 times $(15.83 \rightarrow 35.58 \mathrm{mg} / \mathrm{mL})$ of the heat treated control.
\end{abstract}

Keywords Cell lytic enzyme $\cdot$ Defatted sesame meal $\cdot$ Heat treatment $\cdot$ Protein extraction $\cdot$ Proteolytic enzyme

Man-Jin In $(\triangle)$

E-mail: manjin@chungwoon.ac.kr

${ }^{1}$ Department of Chemical Engineering, Chungwoon University, Incheon 22100, Republic of Korea

This is an Open Access article distributed under the terms of the Creative Commons Attribution Non-Commercial License (http://creativecommons. org/licenses/by-nc/3.0/) which permits unrestricted non-commercial use, distribution, and reproduction in any medium, provided the original work is properly cited.

\section{서 론}

우리나라의 중요한 유지자원인 참깨(Sesamum indicum L.)는 종 자에 45-63\%의 지방이 함유되어 있어 식용유지를 얻는 자원으 로 오랫동안 선호되어 왔으며, sesamol, sesamin, sesamolin 등 과 같은 lignan 성분이 함유되어 있어 항산화 활성 등의 생리 활성도 갖는 우수한 식품재료이다[1]. 참깨의 단백질은 식물성 단백질 중 특이하게 필수 아미노산인 methionine과 tryptophan 의 함량이 우수하여[2] 상대적으로 methionine이 부족한 대두, 땅콩과 같은 식품의 영양학적 가치를 보완할 수 있으므로 음료 와 빵에서 활용[3]되는 것처럼 잠재력이 큰 식품소재이다. 또한 영양학적인 효과 이외에도 참깨 단백질의 콜레스테롤 대사를 조 절하는 항고지혈 효과[4,5]와, 참깨 단백질 가수분해물에는 $\mathrm{ACE}$ 저해 활성을 갖는 펩타이드가 존재하여 항고혈합 효과를 나타 낸다는 보고[6]를 참고하면 참깨 단백질은 생리적인 기능성 소 재로도 중요한 자원이다. 참기름 제조과정에서 부산물로 남는 참깨박은 단백질이 약 $50 \%$ 정도 함유되어 있으며[2], 다양한 폴리페놀 화합물도 배당체로 함유되어 있어[7] 단백질과 폴리페 놀 화합물의 공급원으로 활용이 기대되는 자원이나 참깨박의 일 부가 사료로 이용되고 대부분은 폐기되고 있는 실정이다. 참깨 박으로부터 단백질 분리를 향상시키기 위한 연구로는 sodium hexametaphosphate 처리[8], 한외여과[9], 방사선 조사[10], 효소 처리[11,12], $\mathrm{pH}$ 조절과 $\mathrm{NaCl}$ 첨가[13] 등의 결과가 보고되어 있 다. 또한 참깨 단백질을 식품 소재로 이용하기 위하여 단백질 분해효소의 처리로 단백질 물성(용해도, 유화능과 유화 안정성, 기포 형성력과 기포안정성 등)의 변화에 관한 보고[14,15]도 있 다. 단백질 분해효소를 이용하여 참깨박에서 단백질을 용출하는 연구로는 단백질 분해효소를 생산하는 Bacillus속 미생물이 생 산한 효소의 사용[16], 단백질과 결합된 phytate를 제거하기 위 하여 protease와 phytase의 혼합 처리[11], 상업용 효소의 처리 [12] 등이 보고되어 있다. 상업용 효소 중에서 Protex $7 \mathrm{~L}$ 의 처 
리가 단백질 추출에 효과적이라는 결과[12]는 참기름 추출 향 상을 목적으로 단백질 분해효소를 참깨에 처리한 것이며, 상세 한 단백질 분해효소의 처리 조건에 대한 연구는 미미하다. 또 한 참깨를 볶는 참기름 착유 공정을 고려하면 효소 처리 효과 를 향상시키기 위해서는 참깨박의 전처리가 필요하다.

따라서 본 연구에서는 참기름 제조공정의 부산물로 생성되는 참깨박을 활용하기 위하여, 특히 영양학적 및 생리적으로 유용 한 참깨 단백질의 가공 소재화에 관한 기초 연구의 일환으로 효소를 이용한 참깨박 단백질의 추출 조건을 검토하였다. 상업 용 단백질 분해효소를 선별하고, 효소처리 조건을 확립하였으며, 효소의 처리 효과를 향상시키기 위한 전처리로 참깨박의 열처 리 조건을 조사하였다. 또한 전처리 후 세포벽 분해효소인 $\beta$ glucanase와 단백질 분해효소의 병용처리가 단백질 추출에 미치 는 효과를 비교하였다.

\section{재료 및 방법}

\section{재료}

탈지 참깨박은 (주)청양식품(안성, 대한민국)에서 참기름 재조 후 부산물로 얻어지는 것을 이용하였으며, 단백질 분해효소인 Alcalase, Neutrase, Protamex, Flavourzyme은 Novozyme사 (Bagsvaerd, Denmark), 세포벽 분해효소인 Tunicase는 Daiwa Kasei사(Osaka, Japan)로부터 구입하였다.

\section{탈지 참깨박 열처리}

입도 200-300 $\mu \mathrm{m}$ 의 탈지 참깨박 분말을 증류수에 $10 \%(\mathrm{w} / \mathrm{w})$ 로 현탁시킨 후 고압멸균기에서 $90,100,110,120{ }^{\circ} \mathrm{C}$ 로 각각 10 분간 열처리하였다. 열처리 후 실온에서 충분히 냉각시킨 다 음 효소처리 시료로 사용하였다.

\section{단백질 분해효소 선별}

탈지 참깨박 분말(입도 200-300 $\mu \mathrm{m})$ 을 증류수에 $10 \%(\mathrm{w} / \mathrm{w})$ 로 현탁시킨 후 $0.1 \mathrm{~N} \mathrm{NaOH}$ 혹은 $\mathrm{HCl}$ 로 각각의 효소 반응 최적 $\mathrm{pH}$ 로 조절한 다음 효소를 참깨박 중량의 $1 \%(\mathrm{w} / \mathrm{w})$ 로 가하고 효소 반응 최적 온도에서 3 시간 동안 진탕하였다. 반응 종료 후 끓는 물에 5 분간 열처리하고 원심분리 $\left(3,000 \times \mathrm{g}, 10 \mathrm{~min}, 4{ }^{\circ} \mathrm{C}\right)$ 하여 상등액을 분석 시료로 활용하였다.

\section{탈지 참깨박 효소처리}

탈지 참깨박의 효소처리는 단백질 분해효소와 세포벽 분해효소 에 대하여 각 효소의 단독 처리(1단 반응)와 순차적 처리(2단
반응)의 두 가지 방법으로 실시하였다.

[1단 반웅] 열처리 후 냉각시킨 탈지 참깨박 현탁액의 $\mathrm{pH}$ 를 $0.1 \mathrm{~N} \mathrm{HCl}$ 또는 $\mathrm{NaOH}$ 로 효소 반응의 최적 조건(Protamex $\mathrm{pH}$ 6.0, Tunicase $\mathrm{pH}$ 8.0)으로 조절하고 효소를 참깨박 중량의 $1 \%(\mathrm{w} / \mathrm{w})$ 첨가한 후 효소 반응 최적 온도(Protamex $50^{\circ} \mathrm{C}$, Tunicase $40^{\circ} \mathrm{C}$ )에서 3 시간 동안 진탕하였다. 진탕 후 열처리로 반응을 종료시킨 후 원심분리 $\left(3,000 \times \mathrm{g}, 10 \mathrm{~min}, 4^{\circ} \mathrm{C}\right)$ 하여 고형 분을 제거하고 상등액을 분석 시료로 활용하였다.

[2단 반웅] 열처리한 탈지 참깨박 현탁액에 대하여 Protamex 를 먼저 처리 후 Tunicase를 사용하는 것과 그 역으로 처리하 는 두 가지 조건으로 실시하였다. 열처리 한 참깨박 현탁액의 $\mathrm{pH}$ 를 $\mathrm{pH}$ 6.0으로 맞추고 Protamex를 참깨박의 $1 \%$ 로 첨가한 다음 $50{ }^{\circ} \mathrm{C}$ 에서 3 시간 반응시킨 후 Tunicase의 최적 반응 조건 $\left(\mathrm{pH} 8.0,40^{\circ} \mathrm{C}\right)$ 에서 Tunicase를 $1 \%$ 첨가하여 3 시간 추가로 반 응시켰다. 두 효소의 처리 순서를 반대로 2 단 반응도 각 효소 의 반응조건에 따라 실시하였다.

\section{단백질 및 고형분 함량}

효소처리 후 원심분리로 얻은 상등액의 단백질 함량은 bovine serum albumin을 표준물질로하여 Lowry법으로 분석하였다. 또 한 상등액의 고형분 함량은 refractometer (PR-32 $\alpha$, Atago사, Tokyo, Japan)로 측정하였다.

\section{통계분석}

결과는 SPSS Statistics (Statistical Package for Social Science, SPSS Inc., Chicago, IL, USA, version 23.0)를 이용하여 t-검 정으로 시료간 유의성을 조사하였다(유의수준 $p<0.05$ ).

\section{결과 및 고찰}

\section{단백질 분해효소 선별}

시료로 사용한 탈지 참깨박의 조단백질 함량을 micro-kjeldahl 법으로 분석한 결과 $33.5 \pm 1.12 \%$ 로 참깨박의 단백질 함량이 약 $50 \%$ 라는 기존의 보고[2,9]와 차이를 보였으며, 이는 참깨의 품 종과 참기름 제조방법의 차이에 기인하는 것으로 사료된다. 탈 지 참깨박으로부터 단백질 추출에 활용할 수 있는 단백질 분해 효소를 선별하기 위하여 $10 \%$ 참깨박 현탁액에 참깨박 중량의 $1 \%$ 로 효소를 첨가하여 반응시킨 후 효소 처리 상등액의 고형 분과 단백질 함량을 분석하여 비교하였다. 그 결과(Table 1), 효

Table 1 Effects of proteolytic enzyme treatments on protein concentration and total solid content in defatted sesame meal hydrolysate

\begin{tabular}{|c|c|c|c|}
\hline Enzymes & Total solid content (bx) & Protein content $(\mathrm{mg} / \mathrm{mL})$ & Reaction conditions \\
\hline Alcalase & $2.9 \pm 0.14^{1) *}$ & $16.30 \pm 1.95^{*}$ & $\mathrm{pH} 7.5,50{ }^{\circ} \mathrm{C}, 3 \mathrm{~h}$ \\
\hline Flavourzyme & $2.9 \pm 0.071^{*}$ & $15.84 \pm 2.11^{*}$ & $\mathrm{pH} 6.0,50{ }^{\circ} \mathrm{C}, 3 \mathrm{~h}$ \\
\hline Nutrase & $2.6 \pm 0.14^{*}$ & $11.50 \pm 0.59$ & $\mathrm{pH} 6.0,50^{\circ} \mathrm{C}, 3 \mathrm{~h}$ \\
\hline Protamex & $3,2 \pm 0.010^{*}$ & $18.11 \pm 2.00^{*}$ & $\mathrm{pH} 6.0,50{ }^{\circ} \mathrm{C}, 3 \mathrm{~h}$ \\
\hline Control & $1.9 \pm 0.035$ & $9.85 \pm 1.71$ & $\mathrm{pH} 6.0,50{ }^{\circ} \mathrm{C}, 3 \mathrm{~h}$ \\
\hline
\end{tabular}

\footnotetext{
${ }^{1)}$ Values were means \pm SD
}

${ }^{2)}$ Data were statistically different from the value of control $\left({ }^{*} p<0.05\right)$ 

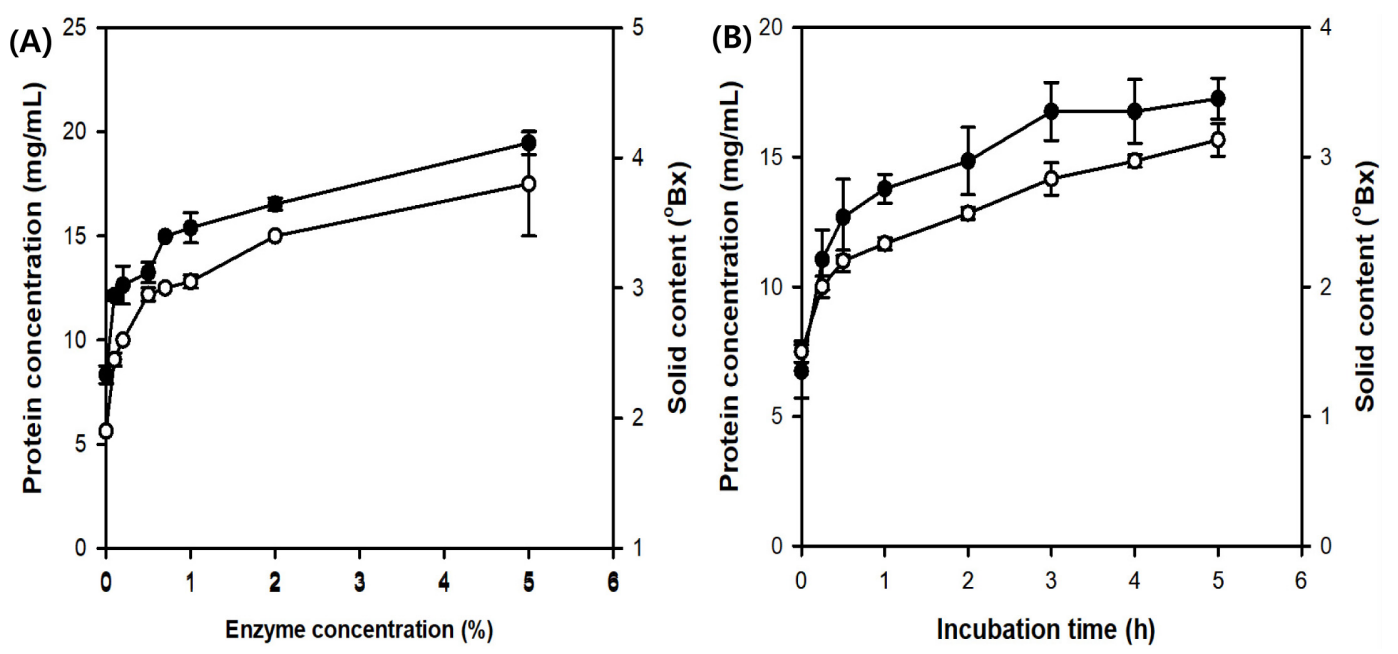

Fig. 1 Effects of dosage (panel A) and incubation time (panel B) of Protamex on protein concentration $(\boldsymbol{O})$ and total solid content $(\bigcirc)$ in defatted sesame meal hydrolysate

소 처리구에서 단백질 함량은 Protamex $>$ Alcalase $>$ Flavourzyme $>$ Neutrase 순으로 대조구보다 $16.8-84.5 \%$ 증가하였으며, 특히 Protamex를 처리한 조건에서 $18.1 \mathrm{mg} / \mathrm{mL}$ 로 대조구의 $9.8 \mathrm{mg}$ $\mathrm{mL}$ 보다 $80 \%$ 이상 증가하였다. 고형분 함량도 단백질 함량과 매우 유사한 경향으로 Protamex 처리에서 $3.2 \mathrm{bx}$ 로 대조구의 $1.8 \mathrm{bx}$ 보다 $70 \%$ 이상 향상되었다. 따라서 참깨박 단백질의 가 용화를 위한 단백질 분해효소는 Protamex가 효과적인 것으로 판단된다. 이상의 결과는 식물 세포벽에 함유된 peptidoglycan 의 단백질 부분이 단백질 분해효소의 처리로 분해되어 다당류 와 단백질의 용해도가 증가하였다는 보고[17] 및 홍삼박의 가 용화를 위한 효소 처리 결과[18]와 매우 유사하였다

\section{단백질 분해효소의 처리 최적화}

선별한 단백질 분해효소 Protamex의 처리 농도와 반응시간의 영향을 조사하였다. 최적 처리 농도를 설정하기 위하여 참깨박 $10 \%(\mathrm{w} / \mathrm{w})$ 현탁액 $(\mathrm{pH}$ 6.0)에 Protamex를 참깨박 중량의 0.1 $5.0 \%$ 로 첨가하여 $50{ }^{\circ} \mathrm{C}$ 에서 3 시간 반응시키고 상등액의 단백질 과 고형분 함량을 측정하였다. 단백질 함량은 효소 처리 농도 $1.0 \%$ 까지 효소 사용량에 비례하여 급격하게 증가하였으며, 그 이상의 조건에서 단백질 함량은 매우 완만하게 증가하였다(Fig. $1 \mathrm{~A})$. 또한 고형분 함량도 단백질 함량과 매우 유사하게 증가하 였다. Protamex $1.0 \%$ 처리 결과를 대조구와 비교하면 단백질 함량은 $8.3 \mathrm{mg} / \mathrm{mL}$ 에서 $15.4 \mathrm{mg} / \mathrm{mL}$ 로, 고형분 함량은 $1.9 \mathrm{bx}$ 에 서 $3.1 \mathrm{bx}$ 로 증가하였다. 따라서 경제적인 측면까지 고려하면 Protamex의 사용량은 참깨박 중량의 $1.0 \%$ 가 적합한 것으로 판 단된다. 최적의 효소 반응시간을 결정하기 위하여 Protamex $1.0 \%$ 조건에서 반응시간에 따른 고형분과 단백질 함량의 변화 를 조사하였다. 고형분과 단백질 함량은 반응 1 시간까지 빠르 게, 그 이후 3 시간까지 완만하게 증가하였으며 5시간까지는 미 미하게 변화하였다(Fig. 1B). 따라서 Protamex의 최적 반응시간 은 3시간으로 결정하였다. 이상의 결과는 단백질 분해효소를 클 로렐라와 홍삼 추출물의 제조에 활용하는 기존의 보고와 매우 유사하였다. 즉, 클로렐라 추출물에는 Esperase $1.0 \%$ 첨가와 3 시간 반응[19], 홍삼 추출물 제조에는 Alcalase $2.0 \%$ 첨가와

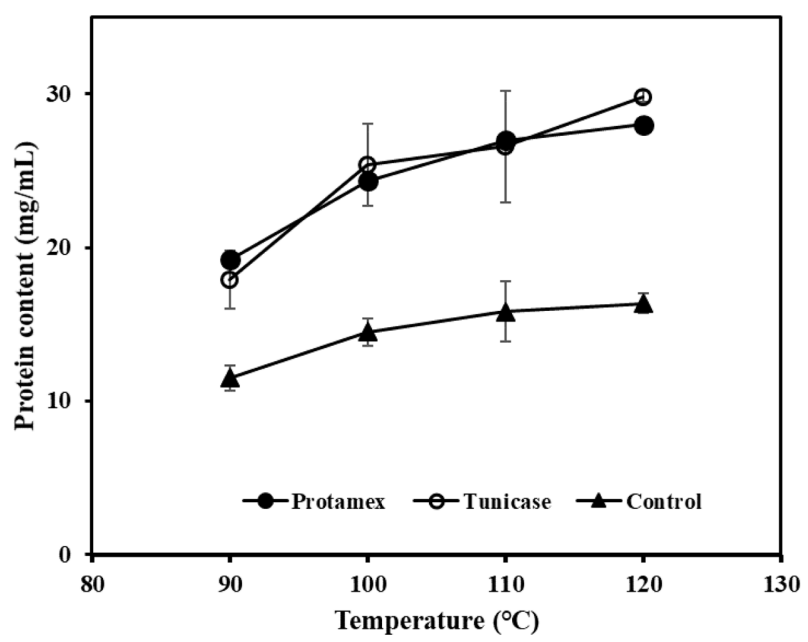

Fig. 2 Effect of pre-treatment temperature on protein concentration in enzymatically hydrolyzed defatted sesame meal

1.5 시간 반응[20]시키는 것이 최적 조건이었다.

\section{열처리 효과}

참기름의 제조공정에서 참기름의 수율을 향상시키고 부수적으 로 풍미를 보완하기 위하여 참깨를 볶는 공정과 압착에 의한 채유 공정이 일반적이다[21]. 그러므로 탈지 참깨박의 단백질은 열과 압력으로 인하여 변성되어 탈지 대두박과 유사하게 단단 한 형태로 존재하므로 효소처리의 효율을 향상시키기 위하여는 시료의 전처리가 필요하다[22]. 참깨박 현탁액을 $90-120^{\circ} \mathrm{C}$ 로 각 각 10 분간 열처리한 후 단백질 분해효소인 Protamex를 본 연 구에서 확립된 조건으로 처리하여 단백질 함량의 변화를 조사 하였다. 또한 식물성 원료로부터 추출물을 제조하는 경우 세포 벽 분해효소의 사용이 효과적이라는 보고[18,20]에 따라 단백질 분해효소와 함께 세포벽 분해효소의 사용을 조사하였다. 본 연 구에서는 Arthrobacter sp. ATCC 21712 기원의 $\beta$-glucanase 활성을 갖는 상업용 세포벽 분해효소인 Tunicase를 사용하였다. 
Table 2 Effect of enzyme treatment methods on protein content in defatted sesame meal hydrolysate

\begin{tabular}{|c|c|c|c|}
\hline Enzyme treatments & Reaction conditions & Protein content $(\mathrm{mg} / \mathrm{mL})$ & Relative protein content \\
\hline \multicolumn{4}{|l|}{ One-step hydrolysis, Non-heated } \\
\hline Protamex $(1 \%)$ & $\mathrm{pH} 6.0,50{ }^{\circ} \mathrm{C}, 3 \mathrm{~h}$ & $15.39 \pm 0.94^{1) *}$ & 1.56 \\
\hline Tunicase $(1 \%)$ & $\mathrm{pH} 8.0,40^{\circ} \mathrm{C}, 3 \mathrm{~h}$ & $11.24 \pm 0.87$ & 1.14 \\
\hline Control $1^{3)}$ & $\mathrm{pH} 6.0,50{ }^{\circ} \mathrm{C}, 3 \mathrm{~h}$ & $9.85 \pm 1.71$ & 1.00 \\
\hline \multicolumn{4}{|c|}{ One-step hydrolysis, Heat treatment $\left(110^{\circ} \mathrm{C}, 10 \mathrm{~min}\right)$} \\
\hline Protamex $(1 \%)$ & $\mathrm{pH} 6.0,50{ }^{\circ} \mathrm{C}, 3 \mathrm{~h}$ & $26.98 \pm 2.13 *$ & 2.74 \\
\hline Tunicase $(1 \%)$ & $\mathrm{pH} 8.0,40^{\circ} \mathrm{C}, 3 \mathrm{~h}$ & $26.57 \pm 3.61 *$ & 2.70 \\
\hline Control $2^{4)}$ & $\mathrm{pH} 6.0,50{ }^{\circ} \mathrm{C}, 3 \mathrm{~h}$ & $15.83 \pm 1.97 *$ & 1.61 \\
\hline \multicolumn{4}{|c|}{ Two-step hydrolysis, Heat treatment $\left(110^{\circ} \mathrm{C}, 10 \mathrm{~min}\right)$} \\
\hline Protamex $\rightarrow$ Tunicase & $\mathrm{pH} 6.0,50,3 \mathrm{~h} \rightarrow \mathrm{pH} 8.0,40{ }^{\circ} \mathrm{C}, 3 \mathrm{~h}$ & $35.58 \pm 1.02 *$ & 3.61 \\
\hline Tunicase $\rightarrow$ Protamex & $\mathrm{pH} 8.0,40,3 \mathrm{~h} \rightarrow \mathrm{pH} 6.0,50{ }^{\circ} \mathrm{C}, 3 \mathrm{~h}$ & $32.26 \pm 1.40^{*}$ & 3.28 \\
\hline
\end{tabular}

\footnotetext{
${ }^{1)}$ Values were means $\pm \mathrm{SD}$

${ }^{2)}$ Data were statistically different from the value of control $1(* p<0.05)$

${ }^{3)}$ Non-heated defatted sesame meal was incubated at reaction conditions without enzyme addition
}

${ }^{4)}$ Heat-treated defatted sesame meal was incubated at reaction conditions without enzyme addition

그 결과(Fig. 2), 열처리 온도가 증가할수록 추출되는 단백질 함 량은 증가하였으며 $110{ }^{\circ} \mathrm{C}$ 이상에서는 미미하게 증가하였다. 110 ${ }^{\circ} \mathrm{C}$ 로 10 분간 가열 후 Protamex와 Tunicase를 각각 처리한 결과 단백질 함량은 26.98 와 $26.57 \mathrm{mg} / \mathrm{mL}$ 로 가열 없이 효소처리한 결 과(Protamex, $15.39 \mathrm{mg} / \mathrm{mL}$; Tunicase, $11.24 \mathrm{mg} / \mathrm{mL}$ ) 보다 크게(Proramex, 75\%: Tunicase, 136\%) 향상되었다. 이때 가열 처리만으로는 단백질 함량이 9.85 에서 $15.58 \mathrm{mg} / \mathrm{mL}$ 로 $58 \%$ 향 상되었다. 또한 가열 전처리에 의한 고형분 함량의 변화도 단 백질 함량의 변화와 유사한 경향이었다(데이터 제시는 생략함). 따라서 탈지 참깨박의 전처리로 $110^{\circ} \mathrm{C}$ 에서 10 분간 가열하는 것 이 적당하였다. 이러한 결과는 탈지 대두박의 효소분해에서 가 수분해도를 향상시키기 위한 $120{ }^{\circ} \mathrm{C}$ 에서 10 분간 가열처리하는 보고[22]와 매우 유사하였다.

\section{세포벽 분해효소와 단백질 분해효소의 처리}

복수의 효소를 사용하는 경우 효소들의 반응 조건이 비슷한 경 우 효소를 동시에 처리하는 것이 효과적일 수 있다[23]. 그러나 본 연구에서 Protamex $\left(50^{\circ} \mathrm{C}, \mathrm{pH}\right.$ 6.0)와 Tunicase $\left(40^{\circ} \mathrm{C}\right.$, $\mathrm{pH}$ 8.0)는 반응 온도와 $\mathrm{pH}$ 가 상이하여 두 효소를 동시에 처리 하는 것보다 순차적으로 처리하는 것이 바람직하였다. 열처리한 참깨박을 원료로 참깨박 $10 \%$ 현탁액 $(\mathrm{pH} \quad 6.0)$ 에 1 차로 Protamex를 $1 \%$ 첨가하여 $50{ }^{\circ} \mathrm{C}$ 에서 3 시간 반응시킨 후 반응 조건 $\left(\mathrm{pH} 8.0,40{ }^{\circ} \mathrm{C}\right)$ 을 조절하여 Tunicase를 $1 \%$ 첨가하고 3 시 간 추가로 처리한 후 상등액의 단백질 함량을 분석하였다. 또 한 Tunicase, Protamex의 순서로 반응시킨 결과와 Protamex와 Tunicase만을 각각 처리한 결과도 정리하였으며, 열처리 없이 효 소로만 반응시킨 결과도 함께 제시하였다(Table 2). 그 결과, Protamex, Tunicase의 순서로 2단 반응 결과는 Protamex로 반 응시킨 결과보다 단백질 함량이 약 $32 \%(26.98 \rightarrow 35.58 \mathrm{mg} / \mathrm{mL})$ 증가하였다. 또한 Tunicase를 먼저 사용하는 2단 반응에서 단백 질 함량은 $32.26 \mathrm{mg} / \mathrm{mL}$ 로 Protamex를 먼저 사용하는 것보다 다소 낮은 결과를 보였다. 가열과 효소처리를 하지 않은 대조 구(control 1)의 기준으로 단백질 함량은 단순한 열처리에 의하
여 1.61배, 열처리 후 Protamex 처리에 의하여 2.74배, 그리고 Tunicase를 추가로 반응시키면 3.61배 향상되었다. 따라서 탈지 참깨박을 열처리 한 후 Protamex와 Tunicase를 순차적으로 처 리하는 것이 단백질 추출에 매우 효과적이었다. 본 연구 결과 를 스피루리나 추출물의 제조에서는 1 차 세포벽 분해효소, 2 차 단백질 분해효소의 순차적 처리가 효율적이라는 보고[24]와 비 교하면 본 연구와 상이하게 스피루리나에서 세포벽 분해효소의 우선 사용이 효과적인 것은 건조한 스피루리나 세포와 착유 과 정에서 세포벽의 물리적인 손상이 발생된 참깨박의 시료 차이 에 기인하는 것으로 사료된다.

\section{초 록}

참기름 제조의 부산물인 참깨박의 활용도를 높이기 위하여 효 소 처리에 의한 참깨박 불용성 단백질의 추출 조건을 조사하였 다. 단백질 분해효소인 Alcalase, Flavourzyme, Neutrase, Protamex의 처리 결과를 대조구와 비교한 결과 Protamex가 고 형분과 단백질 함량 증가에 효과적이었다. Protamex의 반응 조 건 $\left(50^{\circ} \mathrm{C}, \mathrm{pH} 6.0\right)$ 에서 효소의 사용량은 탈지 참깨박의 $1 \%$, 효 소반응시간은 3시간이 적당하였다. 효소 처리 효율을 향상시키 기 위하여 참깨박을 열처리하면, 열처리 온도가 증가할수록 추 출되는 단백질 함량은 증가하였으며 110 이상에서는 미미하게 증 가하였다. 세포벽 분해효소(Tunicase)와 단백질 분해효소의 병용 처리가 단백질 가용화에 미치는 효과를 조사한 결과, 단백질 분 해효소를 처리한 다음에 세포벽 분해효소를 처리하는 것이 가 장 효과적이었다. 열처리 $\left(110^{\circ} \mathrm{C}, 10\right.$ 분 $)$ 후 Protamex와 Tunicase 를 순차적인 처리로 단백질 함량이 열처리와 효소처리하지 않 은 대조구의 약 3.6 배 $(9.85 \rightarrow 35.58 \mathrm{mg} / \mathrm{mL})$, 열처리만 실시한 대조구의 약 2.2 배 $(15.83 \rightarrow 35.58 \mathrm{mg} / \mathrm{mL})$ 증가하였다.

Keywords 단백질 분해효소 - 단백질 추출 - 세포벽 분해효소 열처리 · 참깨박 
감사의 글 본 연구는 2020 년 청운대학교 학술연구조성비의 지원을 받아 수 행하였습니다.

\section{References}

1. Ryu SN, Kim KS, Lee EJ (2002) Current status and prospects of quality evaluation in sesame. Korean J Crop Sci 47: 140-149

2. Johnson LA, Suleiman TM, Lusas EW (1979) Sesame protein: A review and prospectus. J Am Oil Chem Soc 56: 463-468

3. El-Adawy TA (1995) Effect of sesame seed proteins supplementation on the nutritional, physical, chemical and sensory properties of wheat flour bread. Plant Food Human Nutr 48: 311-326

4. Rajamohan T, Kurup PA (1997) Lysine: arginine ratio of a protein influences cholesterol metabolism. Part 1-Studies on sesame protein having low lysine: arginine ratio. Indian J Exp Biol 35: 1218-1223

5. Biswas A, Dhar P, Ghosh S (2010) Antihyperlipidemic effect of sesame (Sesamum indicum L.) protein isolate in rats fed a normal and high cholesterol diet. J Food Sci 75: H274-H279

6. Nakano D, Ogura K, Niyakoshi M, Ishii F, Kawanishi H, Kurumazuka D, Kwak CJ, Ikemura K, Takaoka M, Moriguchi S, Iino T, Kusumoto A, Asami S, Shibata H, Kiso Y, Matsumura Y (2006) Antihypertensive effect of angiotensin 1-converting enzyme inhibitory peptides from a sesame protein hydrolysate in spontaneously hypertensive rats. Biosci Biotechnol Biochem 70: 1118-1126

7. Mohdaly AA, Sarhan MA, Smetanska I, Mahmoud A (2010) Antioxidant properties of various solvent extracts of potato peel, sugar beet pulp and sesame cake. J Sci Food Agric 90: 218-226

8. Rhee JS, Park JR (1993) Effect of sodium hexametaphosphate on the extractability of sesame meal protein and amino acid composition and color of its protein concentrate. J Korean Soc Food Nutr 22: 758-762

9. Jeon JR, Park JR (2000) Functional properties of sesame protein concentrates produced by ultrafiltration. J East Asian Soc Dietary Life 10: 394-403

10. Cho YJ, Kim JK, Cha WS, Park JH, Oh SL, Byun MW, Chun SS, Kim SH (1999) Change of physical properties and extraction of sesame meal protein by gamma irradiation. Korean J Food Sci Technol 31: 924-930

11. Chun SS, Cho YJ, Cho KY, Choi C (1998) Change of functional properties and extraction of sesame meal protein with phytase and protease. Korean J Food Sci Technol 30: 895-901

12. Latif S, Anwar F (2011) Aqueous enzymatic sesame oil and protein extraction. Food Chem 125: 679-684

13. Achouri A, Nail V, Boye JI (2012) Sesame protein isolate: Fractionation, secondary structure and functional properties. Food Res Int 46: 360-369

14. Lee SH, Cho YJ, Kim S, Ahn BJ, Choi C (1995) Optimal conditions for the enzymatic hydrolysis of isolated sesame meal protein. Agric Chem Biotechnol 38: 248-253

15. Lee SH, Cho YJ, Chun SS, Kim YH, Choi C (1995) Functional properties of proteolytic enzyme-modified isolated sesame meal protein. Korean J Food Sci Technol 27: 708-715

16. Choi C, Chun SS, Cho YJ (1993) Extraction of protein from defatted sesame meal using the enzyme from Bacillus sp. CW-1121. J Korean Agric Chem Soc 36: 121-126

17. Chae HJ, Han MS, In MJ (2004) Study on utilization of vegetable byproduct from food processing by enzyme treatment. J Korean Soc Appl Biol Chem 47: 146-148

18. Kim DC, In MJ (2010) Production of hydrolyzed red ginseng residue and its application to lactic acid bacteria cultivation. J Ginseng Res 34: 321-326

19. In MJ, Jang JE, Kim DH (2007) Enhancing extraction yield of chlorella extract by enzyme treatment. J Appl Biol Chem 50: 132-135

20. Kim DC, Lee TJ, In MJ (2019) Potential of proteolytic enzyme treatment for production of Korean red ginseng extract. J Appl Biol Chem 62: 385-389

21. Cha YH, Cho SC, Kang BS, Han MR, Cho EA (2016) Food processing preservation. Powerbook, Goyang, Korea

22. Chae HJ, In MJ, Kim MH (1998) Process development for the enzymatic hydrolysis of food protein: Effects of pre-treatment and posttreatment on degree of hydrolysis and other product characteristics. Biotechnol Bioprocess Eng 3: 35-39

23. In MJ (2009) Effect of enzyme treatments on the extraction efficacy and antioxidant activity of heamatococcus extract from Haematococcus pluvialis. J Korea Acad-Ind Cooper Soc 10: 194-199

24. In MJ (2008) Optimization of proteolytic enzyme treatment for the production of spirulina extract. J Korea Acad-Ind Cooper Soc 9: 550 555 